\title{
TECHNIQUES FOR IMPLEMENTING FORM AND COLOR IN THE ARTISTIC DESIGN OF ARCHITECTURAL AND URBAN ENVIRONMENT
}

\author{
Praslova V.O., PhD of Architecture, Associate Professor, \\ praslova.vo@knuba.edu.ua, z-design@ukr.net, ORCID: 0000-0002-9342-6996 \\ Kyiv National University of Construction and Architecture \\ 31, Povitroflotsky Ave., Kyiv, 03037, Ukraine
}

\begin{abstract}
The results of scant attention to questions of artistic cultural decay and esthetic expressiveness are critical condition and often lack of artistic emotional and figurative perception of urban architectural environment and most of public and housing objects in Ukraine. One of the ways of dealing with this problem is implementation of specified means and techniques of artistic design.

Many scientists research color and form impact on the urban architectural environment, however the attention is paid to the solution of general theoretical questions often ignoring artistic factor. That's why it is important to systematize information about means of formation of emotional and figurative perception of urban architectural environment accounting artistic factor and determine artistic techniques for form and color implementation to urban architectural environment.

The aim and tasks of work are to systematize information about means for emotional and figurative perception of urban architectural environment using artistic factor, determine techniques for implementing main tools of artistic design to architectural and urban environment.

Therefore, analysis and systematization of scientific research results, literary and informational sources revealed that such tools as form and color have the most significant influence on the formation of emotional and figurative perception of urban architectural environment within artistic design. As the result of the comparative analysis of existing knowledge six artistic techniques of implementing form and color to architectural and urban environment are presented. Among them are technique of polar contrast utilization, technique of highlighting, technique of rhythm, technique of dynamism or transparency, technique of expressiveness and technique of form and color subjectivity.

Above mentioned techniques for implementing form and color to architectural and urban environment are basic for the development of the author's own language of self-realization by architect-artist. Using these techniques both together and separately, their successful combination can create an architectural and urban environment with a unique atmosphere, which is in development and changes constantly, dictates its own rules of perception, elicit an individual emotional response from every visitor.
\end{abstract}

Keywords: artistic design, emotional and figurative perception, artistic image, architectural and urban environment, theory of architecture.

Introduction. The results of scant attention to questions of artistic cultural decay and esthetic expressiveness, which have been going on since the period of the World Industrial Revolution are critical condition and often lack of artistic emotional and figurative perception of urban architectural environment and most public and residential buildings in Ukraine. One of the ways of dealing with this problem is implementation of specified means and techniques of artistic design. In particular, with the right chosen artistic techniques of implementing form and color the classic stereotypes and images of architectural and urban environment and objects are destroyed. That, in its turn provokes users to reconsider the existing environment and encourages the development of new emotional and figurative characteristics of surroundings. In this manner ordinary way of life is changing, and positive influence and qualitative rethinking of the architectural and urban environment and people's everyday life are happening $[1,5,7,8]$.

The analysis of recent researches and publications. One of the pioneers in the theory of artistic expressiveness in terms of artistic design abroad was Johannes Itten during his work at the Bauhaus. The priority means for achievement of artistic expressiveness for him were means that could help the

Bulletin of Odessa State Academy of Civil Engineering and Architecture, 2020, no. 81, page 26-32 
author to show his creative individuality and independence. Itten's artistic language relies on objective laws as in color formation as in form formation[5]. Modern extremely interesting research is conducted at educational center The Why Factory led by MVRDV co-founder, professor Winy Maas from the architectural faculty of Delft University of Technology. The analytical work of The Why Factory is based on knowledge in the field of architecture, urbanism, sustainable development, sociology, development of the newest materials. Radical ideas about the future of the urban and architectural environment are considered. The founder of the domestic school of artistic design is Eugene Rozemblum, who together with the architects Bokov A.V., Glazychev V.L. and artists Konik M.O., Lindin S.Y. created the Senezh Studio to study the experience of the Bauhaus, the Higher Art and Technical Workshops and the Higher Art and Technical Institute. The result of the studio was the development of its own language of artistic design by focusing on art and awareness of artistic design as an independent and autonomous creative school of design [4, 7]. The issues of esthetic qualities of the architectural environment are explored by Arnheim R., Bozhko G.B., Bulakh I.V., Zabelshansky G.B., Ikonnikov A.V., Ladovsky N.O., Marder A.P., Nekrasov I.S., Norberg-Schultz Kr., Rappaport O.G., Somov G.Yu., Stepanov O.V., Timokhin V.O., Shevelyov I.Sh., Shchurova V.A., Ushakov G.N. and others $[1,12,13]$.

Problem statement. Many scientists study the influence of color and form on the architectural and urban environment, but attention is paid to solving general theoretical issues, often ignoring the artistic factor. Therefore, it is necessary to agree on the means of forming an emotional and figurative perception of the architectural and urban environment, taking into account the artistic factor and to determine the artistic methods of introducing form and color in the architectural and urban environment.

Aim and tasks of work are to systematize information about means for emotional and figurative perception of urban architectural environment using artistic factor, determine techniques for implementing main tools of artistic design to architectural and urban environment.

Materials and methods of research. The main things for artistic design are the emotional content and figurative perception of environmental objects and systems that form their own architectural and urban environment. The emotional impact on the user creates a unique artistic image of the environment and elevates it to the same level as works of art. As a result of the analysis of information sources, six techniques of creating an artistic image are systematized and formulated by introducing form and color within the artistic design of objects of urban and architectural environment. In particular, "The Art of Form" and "The Art of Color" reveal and emphasize such techniques of achieving emotional impact on the user and creating a figurative perception of the environment as contrasting relationships, emphasis, rhythm, expressiveness and subjectivity. Successful operation of these techniques is able to create an architectural and urban environment with a unique atmosphere, to convey the individuality and originality of the author's idea $[5,7,9]$.

The first method of achieving emotional impact and creating a figurative perception of the environment is polar contrast utilization of shape and color. The practical achievements of modern objects of artistic design demonstrate almost complete abandonment of the utilization of nuanced relations, successfully illustrating this theoretical statement. The three brightest polar contrast ratios are "big-small", "cold-warm" and "black and white". After all, these contrasts successfully demonstrate the greatest difference between objects. It should be noted that in its pure form, these relationships are quite rare. Often the technique of the contrast correlation is joined by the technique of displacement or, as it is also called, shift. It is implied that opposites always coexist side by side. In particular, white is introduced into black, as dark shades work well on a light background. In this way, it is possible to express the play of light and shadow during artistic design, to strengthen the plasticity of the shape of the objects of the environment. In the work "The Art of Form" we are talking about seven types of color contrasts. Each contrast is characterized by a certain artistic expression and its own impact on the viewer. Analysis of practical achievements has shown that some of them are used in artistic design often, others are used rarely or almost not used. The first type is color contrast comparisons or color contrast. This is a voluntary comparison of two of the three or the simultaneous use of three pure colors at once: blue, yellow and red. They are called primary and are the basis for the color wheel developed by Itten. This type of contrast is most often used in the creative work of artists in artistic design, as it is 
the most expressive. The combination of colors allows you to convey different emotions due to a certain emotional impact of each color: joy, sadness, greatness, humiliation, etc. [2, 6]. Extremely common in artistic design is also the contrast of the area of the color spot, which is achieved by contrasting the colored surfaces of different sizes. This contrast allows you to create a new meaning and to form a certain emotional perception of the environment by violating Itten's recommendations to select an area proportional to the brightness of colors. After all, due to the violation of optical balance, despite the obvious dominance of one color, the second color is perceived brighter than the first, even when the colors have the same brightness. Itten notes that a color that occupies a smaller area tries to resist the dominance of a larger color $[4,6]$. Often in works of art the contrast of cold and warm colors, such as red-orange and blue-green is used. Itten notes that cold and warm colors enhance each other's influence and create a sense of interaction and a kind of conflict of opposites [4, 6]. Quite often, architects and artists use the contrast of additional colors, which are opposite in the color wheel of Itten. Often a pair of complementary colors combines several types of contrast. For example, the contrast of additional colors is joined by the contrast of light and dark, or the contrast of cold and warm $[3,6]$. The next extremely important and common in use is simultaneous contrast. It is an optical component of all works of artistic design and arises due to the fact that the eye tries to find the color balance, deliberately disturbed during the work of the author. The longer you look at an artwork, the better you see not only the colors actually depicted, but the colors that are actually missing (additional to portrayed) [3, 6]. Rarely in artistic design the contrast of color saturation is used, in which there is a contrast of saturated and dim colors. It is characterized by the usage of colors of different brightness and hue by introducing white (lightening) or black (darkening) in pure colors. In Itten's color wheel, pure colors are the colors of the twelve segments. Dark and light shades of the same color evoke different emotions and different emotional effects. For example, Itten characterizes dark purple shades as those in which there is a threat. But from the light shades of purple, he, in reverse, notes a pleasant and calm and cheerful impression $[2,3,6]$.

For organization the emotional and figurative perception of the architectural and urban environment from the standpoint of form in artistic design the contrast of two of the three basic forms according to Itten is typical: square, triangle and circle [6]. By "square" we mean all figures constructed on the basis of the intersection of parallel horizontal and vertical lines. These are a square, cross, cube, parallelepiped, and so on. The "triangle" includes all figures built at the intersection of diagonals. For example, such forms include a triangle, a rhombus, a trapezoid, a pyramid, and so on. The "circle" includes figures built with a compass. These are curved shapes of a curvilinear nature. Such as circle, oval, ellipse, parabola, layer, cone. Therefore, due to the usage of the contrast comparisons of two of the three main forms, variations and combinations of opposites are created, which evoke a certain emotional response and enhance the perception of environmental objects and architectural and urban environment $[6,9,12]$.

The next typical method of forming and strengthening the emotional and figurative perception of the architectural and urban environment in artistic design is technique of highlighting and conscious refusal to introduce the dominant. This technique is able to form the emotional and figurative expressiveness of the environment and further influence the person not only in artistic design. Accentuation is also widely used in architecture, music, choreography, poetry, cinema, theater, performances, happenings, etc. In environmental projects at all levels: urban planning, architecture and design, the dominant distracts from less active but no less important for the perception of intermediate points of the environment. As a result, a person during the perception of the environment loses important moments and processes for understanding. It causes negative emotions, feelings of helplessness, irritability and excitement. Unlike the dominant, accents promote holistic perception and have a positive effect on the user's understanding of the environment and all the processes that take place in it. There are rules of an arrangement of accents for each form at construction. The location of accents on the axes and diagonals is common. This is actively used by authors of art projects to enhance the expressiveness and emotional and figurative perception of the environment. In this way, artistic objects are introduced into the urban environment, which deliberately fall out of the existing monotonous architectural and urban context. Highlighting is also used in artistic design during the creation of architectural objects and the subject content of the architectural environment. As a result,

Bulletin of Odessa State Academy of Civil Engineering and Architecture, 2020, no. 81, page 26-32 
works of art develop their own rules of perception, provoke a unique emotional response from each visitor and change the existing reality in accordance with the author's intention $[6,10,14]$.

No less important method of forming emotional and figurative perception and, accordingly, the unique atmosphere of the environment is technique of rhythm and deliberate rejection of any metric constructions. As Itten points out, rhythm is always inherent in continuous arbitrary motion. For example, the rhythm of dance, the rhythm of tides, the rhythm of music, and so on. Therefore, in class, he taught students to find rhythm in repetitions and consonances of points, lines, geometric shapes, spots, volumes, proportions, textures, colors. It happened in an extremely unusual and interesting way. The lesson has dictation with one repeated phrase. Gradually the reading speed increased by two, then three or more times. As the speed increased, the letters changed their classical proportions and took on a strange shape. Therefore, it was possible to observe a visual manifestation of rhythm. The same thing happens during experiments with geometric and natural shapes, because these shapes are related and used building a font. Therefore, Itten proves the rule that different in nature forms are able to unite into a single whole with a common rhythm under the condition of creating an object in a single continuous motion $[6,12]$.

Constant movement and changes, the dynamics of the elements of the architectural and urban environment as a separate phenomenon were realized and turned into a unique method of design by architects and artists of the Senezh Studio. Thus, the method, which in the theoretical achievements of artistic design is called the open form method, allowed a person to change the characteristics of created art objects individually, influencing the existing architectural and urban environment and adapt the environment to themselves. This method should be considered as another important method of forming an emotional and figurative perception of the environment not only from the standpoint of changing the form. The technique of dynamism or transparency works also well for such means of artistic design as color. In this case, the architect-artist who is the author of the project is required to include in the project a further possibility to change the color and shape of the objects of the environment. After all, the ability to change the shape and color undoubtedly affects the emotional and figurative perception of the environment due to the ability to change the broadcast of emotions $[5,8]$.

Expressiveness is the basis in artworks and no less important method of emotional and figurative formation of objects and architectural environment. Expression is demonstrated in music through the use of human language intonation to convey mood. Music is able not only to convey feelings, but also to awaken them in a person, to cause emotional resonance. Fine art has more complex and ambiguous means of expression. It affects the emotional sphere of a person through color, expression of strokes, the dynamics of lines, shapes. It is worth mentioning the works of impressionist artists who use color to convey the nuances of mood. Dance and ballet use the expression of movements that are no less expressive than sounds, words, shape and color. The theater uses the full range of expressive means available to man. In artistic design, the expressiveness of objects and environment is greatly enhanced not only by contemplation, but also by involving people in the design process itself through happenings and performances [7, 10, 11]. Johannes Itten explains the concept of expressive form on the example of the principle of work of Chinese painters with a brush: "Hand and heart must be one". Bearing in mind that the author's own experience and peculiarities of perception determine the uniqueness of the artwork created by him. With the help of basic straight and curved lines, a certain color and shape of the elements of the environment and the movement any creative impulse could be expressed. Generalizing a certain emotional and spiritual life experience leads to the creation of an image that does not depend on what you knew before. Therefore, the emotional and spiritual content, which devolves into form and color, turns the architectural and urban environment into an artwork [6, 7, 12].

An important method of forming the emotional and figurative perception of the environment is the subjectivity of form and color. In particular, the combination of subjective and objective in solving problems of color and shape, Itten considered one of the three main tasks of the educational artistic process. The basics of architectural composition with its laws of formation reveal the objective side of art and architecture. It is the subjective nature of form and color that is responsible for the emergence of emotions, it forms artistic expression and figurative perception of the 
environment. Subjective character is demonstrated in the choice of proportions, interpretation of form, choice of a certain type of contrast, texture, color. All this allows us to interpret the created objects and the architectural and urban environment according to our own "Self". The book "The Art of Form" identifies three types of artists in accordance with the constitution and temperament: material-impressive, intellectually-constructive, spiritually-expressive. The first material-impressive type is characterized by observation of the environment, accuracy in creating of form, attention to details and lack of additions. For the second intellectual-constructive type, the main thing is the constructive nature of the object. These artists try to understand, organize, arrange geometrically. The third spiritually-expressive type of artists works intuitively. These artists are indifferent to form and construction, for them the harmony of color is the most important $[5,11]$. In my opinion, the third type of artists is able to ask questions in creative projects, create conflict situations, encourage people to get out of the comfort zone, provoke changes and break the usual stereotypes. After all, all artistic design projects carry a spirit of denial. They not only pay attention to imperfections and protest against the imperfect, but through protest they also clear the way for everything that is perfect. The choice to accept a challenge or deny the existence of problems, that a person does on a daily basis depends only on the human essence and the strength of the human spirit.

The results of the research. Therefore, analysis of literary and informational sources revealed that such tools as form and color have the most significant influence on the formation of emotional and figurative perception of urban architectural environment within artistic design. As the result of systematization of existing knowledge six artistic techniques for creation of art objects and implementing form and color to architectural and urban environment are presented. Among them are technique of polar contrast utilization, technique of highlighting, technique of rhythm, technique of dynamism or transparency, technique of expressiveness and technique of form and color subjectivity.

The results. Above mentioned techniques for creation of art objects and implementing form and color to architectural and urban environment are the basis for the development of the author's own language of communication and self-realization by architect-artist. Their successful combination can create an architectural and urban environment with a unique atmosphere, which is in development and changes constantly, dictates its own rules of perception, elicit an individual emotional response from every visitor.

\section{References}

[1] I.V. Bulakh, "Artistic and Aesthetic Formation and Evolution of Architectural and Urban Planning Space", Nauka ta innovacii, 15(5), pp. 52-61, 2019. https://doi: 10.15407/scin15.05.052

[2] Creative Practice. Kolirni kontrasty za Ittenom (chastyna 1). [Online]. Available: https://cases.media/column/kolirni-kontrasty-za-ittenom-chastyna-1. Accessed on: September 21, 2020.

[3] Creative Practice. Kolirni kontrasty za Ittenom (chastyna 2). [Online]. Available: https://cases.media/column/kolirni-kontrasti-za-ittenom-chastina-2. Accessed on: September 21, 2020.

[4] Creative Practice. Kolirni kontrasty za Ittenom (chastyna 3). [Online]. Available: https://cases.media/column/kolirni-kontrasti-za-ittenom-chastina-3. Accessed on: September 21, 2020.

[5] V.L. Glazychev, Opyt Senezhskoj studii. [Online]. Available: http://www.glazychev.ru/publications/articles/2004-03-11_opyt_senezh_studii.htm\#12. Accessed on: September 08, 2020.

[6] Johannes Itten, Iskusstvo formy. Moj forkurs v Bauhauze i drugih shkolah. Perevod s nemeckogo i predislovie L. Monahovoj. Shtutgart: Verlagsgruppe Dornier GmbH, 1975.

[7] Informacijnij zhurnal Samorozvitok. Ekspresiya - sho ce i yak vona proyavlyayetsya? Sho take ekspresiya, formi yiyi proyavu. [Online]. Available: https://srcaltufevo.ru/uk/ekspressiya-chto-eto-i-kak-ona-proyavlyaetsya-chto-takoeekspressiya.html. Accessed on: September 08, 2020. 
[8] M.A. Konyk, Arhiv odnoj masterskoj. Senezhskie opyty: uchebnyk. M.: Yndeks Dyzain\&Pablyshynh, 2003.

[9] V.O. Praslova, "Prijomi vprovadzhennya novih budivelnih materialiv v hudozhnomu proektuvanni", Suchasni problemi arhitekturi ta mistobuduvannya, vol. 54, pp. 393-402, 2019.

[10] V.O. Praslova, "Perfomans v khudozhnomu proektuvanni", Suchasni problemy arkhitektury ta mistobuduvannia, vol. 52, pp. 115-120, 2018.

[11] V.O. Praslova, "Khepeninh v khudozhnomu proektuvanni miskoho seredovyshcha", Zbiór artykułów naukowych "Priorytetowe obszary badawcze: od teorii do praktyki", pp. 10-14, 2017.

[12] V.O. Praslova, "Istoriia stanovlennia khudozhnoho proektuvannia", Suchasni problemy arkhitektury ta mistobuduvannia, vol. 29, pp. 126-130, 2012.

[13] H.N. Ushakov, "Vydy vidchuttiv zadovolennia pry spryiniatti arkhitekturnoho seredovyshcha ta umovy yikhnoho formuvannia", Perspektyvni napriamky proektuvannia zhytlovykh ta hromadskykh budivel. vol. Orhanizatsiia komfortnoho seredovyshcha zhyttiediialnosti miskykh poselen, pp. 166-168, 2008.

[14] V.A. Shchurova, "Zakonomirnosti spryiniattia kolorystyky miskoho seredovyshcha", Perspektyvni napriamky proektuvannia zhytlovykh ta hromadskykh budivel. vol. Orhanizatsiia komfortnoho seredovyshcha zhyttiediialnosti miskykh poselen, pp. 161$165,2008$.

\title{
ПРИЙОМИ ВПРОВАДЖЕННЯ ФОРМИ І КОЛЬОРУ В ХУДОЖНЬОМУ ПРОЕКТУВАННІ АРХІТЕКТУРНО-МІСТОБУДІВНОГО СЕРЕДОВИЩА
}

\author{
Праслова В.О., канд. арх., доцент, \\ praslova.vo@knuba.edu.ua, z-design@ukr.net, ORCID: 0000-0002-9342-6996 \\ Київський національний університет будівництва та архітектури \\ пр. Повітрофлотський, 31, м. Київ, 03037, Україна
}

Анотація. Результатами поверхневої уваги до питань занепаду художньої культури і естетичної виразності є критичний стан і часто відсутність художнього емоційно-образного сприйняття архітектурно-містобудівного середовища більшості громадських і житлових об'єктів України. Одним із шляхів подолання цієї проблеми є застосування певних засобів і прийомів художнього проектування.

Дослідженнями впливу кольору і форми на архітектурно-містобудівне середовище займаються багато вчених, однак увага приділяється вирішенню загальних теоретичних питань часто без урахування художнього фактору. Тому слід систематизувати інформацію про засоби формування емоційно-образного сприйняття архітектурно-містобудівного середовища з урахуванням художнього фактора і визначити художні прийоми впровадження форми і кольору в архітектурно-містобудівне середовище.

Метою і завданнями роботи $є$ систематизація інформації про засоби формування емоційно-образного сприйняття архітектурно-містобудівного середовища 3 позицій художнього фактору, визначення прийомів впровадження основних засобів художнього проектування в архітектурно-містобудівне середовище.

Аналіз і систематизація результатів наукових досліджень, літературних та інформаційних джерел виявили, що на формування емоційно-образного сприйняття архітектурно-містобудівного середовища в межах художнього проектування найбільший вплив мають такі засоби як форма і колір. В результаті порівняльного аналізу існуючих знань запропоновано шість художніх прийомів впровадження форми і кольору в архітектурномістобудівне середовище. Це прийом використання полярної контрастності, прийом акцентування, прийом ритмічності, прийом динамічності або відкритості, прийом експресивності, прийом суб'єктивності форми і кольору. 
Перераховані прийоми створення архітектурних об'єктів і впровадження форми i кольору в архітектурно-містобудівне середовище $\epsilon$ фундаментом для розвитку архітекторомхудожником власної авторської мови самореалізації. Застосування прийомів можливо як разом, так і окремо. Вдале їх поєднання здатне створити архітектурно-містобудівне середовище 3 неповторною атмосферою, яке розвивається і постійно змінюється, диктує свої правила сприйняття, викликає індивідуальний емоційний відгук у кожного відвідувача.

Ключові слова: художнє проектування, емоційно-образне сприйняття, художній образ, архітектурно-містобудівне середовище, теорія архітектури.

\title{
ПРИЁМЫ ВНЕДРЕНИЯ ФОРМЫ И ЦВЕТА В ХУДОЖЕСТВЕННОМ ПРОЕКТИРОВАНИИ АРХИТЕКТУРНО-ГРАДОСТРОИТЕЛЬНОЙ СРЕДЫ
}

\author{
Праслова В.А., канд. арх., доцент, \\ praslova.vo@knuba.edu.ua, z-design@ukr.net, ORCID: 0000-0002-9342-6996 \\ Киевский национальньй университет строительства и архитектуры \\ пр. Воздухофлотский, 31, г. Киев, 03037, Украина
}

\begin{abstract}
Аннотация. Результатами поверхностного внимания к вопросам упадка художественной культуры и эстетической выразительности является критическое состояние и часто отсутствие художественного эмоционально-образного восприятия архитектурно-градостроительной среды и большинства общественных и жилых объектов Украины. Одним из путей преодоления этой проблемы является применение определенных средств и приемов художественного проектирования.
\end{abstract}

Исследованиями влияния цвета и формы на архитектурно-градостроительную среду занимаются многие ученые, однако внимание уделяется решению общим теоретическим вопросам часто без учета художественного фактора. Поэтому следует систематизировать информацию о средствах формирования эмоционально-образного восприятия архитектурноградостроительной среды с учетом художественного фактора и определить художественные приемы внедрения формы и цвета в архитектурно-градостроительную среду.

Целью и задачами работы является систематизация информации о средствах формирования эмоционально-образного восприятия архитектурно-градостроительной среды с позиций художественного фактора, определение приемов внедрения основных средств художественного проектирования в архитектурно-градостроительную среду.

Таким образом, анализ и систематизация результатов научных исследований, литературных и информационных источников выявили, что на формирование эмоциональнообразного восприятия архитектурно-градостроительной среды в рамках художественного проектирования наибольшее влияние оказывают такие средства как форма и цвет. В результате сравнительного анализа существующих знаний предложено шесть художественных приемов внедрения формы и цвета в архитектурно-градостроительную среду. Это прием использования полярной контрастности, прием акцентирования, прием ритмичности, прием динамичности или открытости, прием экспрессивности и прием субъективности формы и цвета.

Перечисленные приемы создания архитектурных объектов и внедрения формы и цвета в архитектурно-градостроительную среду являются фундаментом для развития архитекторомхудожником собственного авторского языка самореализации. Применение приемов возможно как вместе, так и по отдельности. Удачное их сочетание способно создать архитектурноградостроительную среду с неповторимой атмосферой, которая развивается и постоянно меняется, диктует свои правила восприятия, вызывает индивидуальный эмоциональный отклик у каждого посетителя.

Ключевые слова: художественное проектирование, эмоционально-образное восприятие, художественный образ, архитектурно-градостроительная среда, теория архитектуры.

Стаття надійшла до редакції 8.10.2020 